\title{
Penerapan Model Problem Based Instruction (PBI) dengan Media Kartu Pintar untuk Meningkatkan Kualitas Pembelajaran IPA pada Peserta Didik Kelas IV SDN 211/IX Mendalo Darat
}

\author{
Rosinah $^{1}$ \\ ${ }^{1}$ Guru SD Negeri 211/IX Mendalo Darat \\ Correspondance email: rosinahrosinah07@gmail.com
}

\begin{abstract}
Abstrak: Latar belakang permasalahan dalam pembelajaran IPA, guru kurang melibatkan peseta didik dalam penyelidikan, peserta didik kurang dilatih dalam mengembangkan hasil karya (produk). Konsep-konsep yang dikuasai peserta didik hanya diberikan secara hafalan oleh guru, peserta didik kurang dibelajarkan melalui proses penemuan yang berorientasi pada masalah dalam kehidupan sehari-hari. Berdasarkan masalah tersebut yang paling tepat solusinya adalah menerapkan media kartu pintar dengan model PBI. Secara khusus adalah meningkatkan keterampilan guru, aktivitas peserta didik, dan hasil belajar dalam pembelajaran IPA kelas IV SDN 211/IX Mendalo Darat. Penelitian ini merupakan penelitian tindakan kelas, dan menggunakan model Problem Based Instruction dengan media kartu pintar dalam tiga siklus. Terdiri dari dua pertemuan dan empat tahap dalam setiap, yaitu perencanaan, pelaksanaan, observasi, dan refleksi. Berdasarkan latar belakang tersebut hasil penelitian menunjukkan : (1) keterampilan guru memperoleh rata-rata skor dari dua pertemuan pada siklus 1 adalah 21,5 dengan kriteria cukup; siklus 2 memperoleh skor 27 dengan kriteria baik. Skor yang diperoleh pada siklus 3yaitu 30,5 dan termasuk dalam kategori baik. (2) Aktivitas peserta didik memperoleh rata-rata skor dari dua pertemuan pada siklus 1 adalah 21,85 dengan kriteria cukup; Pada siklus 2 diperoleh skor 24,35 kriteria baik. Untuk siklus 3, diperoleh skor yaitu 31,2 kategori baik. (3) Hasil belajar peserta didik memperoleh rata-rata persentase ketuntasan klasikal dari dua pertemuan pada siklus 1 adalah 55,41\%. Diperoleh persentase ketuntasan klasikal pada siklus 2 adalah 68\%. Persentase ketuntasan klasikal pada siklus 3 yaitu 81\%. Indikator keberhasilan telah tercapai pada hasil penelitian tersebut menunjukkan bahwa penelitian ini dinyatakan berhasil. Melalui model Problem Based Instruction (PBI) dengan media kartu pintar simpulan penelitian ini, dapat meningkatkan keterampilan guru, aktivitas peserta didik dan hasil belajar peserta didik kelas IV SDN211/IX Mendalo Darat. Disarankan bagi guru adalah Sebelum memulai pembelajaran dengan model Problem Based Instruction dengan media kartu pintar guru perlu persiapan matang
\end{abstract}

Kata Kunci : Model Problem Based Instruction (PBI), Kualitas Pembelajaran, Media kartu pintar

\begin{abstract}
The background of the problem in science learning, teachers do not involve students in investigations, students are less trained in developing work (products). The concepts that are mastered by students are only given rote by the teacher, students are not taught through a problem-oriented discovery process in everyday life. Based on this problem, the most appropriate solution is to implement a smart card media with a PBI model. In particular, it is improving teacher skills, student activities, and learning outcomes in science learning for class IV SDN 211 / IX Mendalo Darat. This research is a classroom action research, and uses a Problem Based Instruction model with smart card media in three cycles. Consists of two meetings and four stages in each, namely planning, implementing, observing, and reflecting. The results showed: (1) the skills of the teacher in obtaining an average score of the two meetings in cycle 1 were 21.5 with sufficient criteria; cycle 2 obtained a score of 27 with good criteria. The score obtained in cycle 3 is 30.5 and is included in the good category. (2) The activity of students obtaining an average score from the two meetings in cycle 1 was 21.85 with sufficient criteria; In cycle 2, a score of 24.35 was obtained with good criteria. For cycle 3, obtained a score of 31.2 good categories. (3) The learning outcomes of students obtaining an average percentage of classical completeness from the two meetings in cycle 1 was 55.41\%. Obtained the percentage of classical completeness in cycle 2 is $68 \%$. The percentage of classical completeness in cycle 3 was $81 \%$. The indicators of success that have been achieved in the results of this study indicate that this research is declared successful. Through the Problem Based Instruction (PBI) model with smart card media, the conclusions of this study can improve teacher skills, student activities and learning outcomes of grade IV SDN211 / IX Mendalo Land. It is recommended for teachers that before starting learning with the Problem Based Instruction model with smart card media the teacher needs careful preparation
\end{abstract}

Keywords: Problem Based Instruction (PBI) Model, Quality of Learning, Smart card media

\section{PENDAHULUAN}

Dalam kehidupan sehari-hari salah satu teori yang melandasi adalah mengembangkan pengetahuan dan pemahaman konsep-konsep IPA yang bermanfaat dapat diterapkan. Hubungan yang saling mempengaruhi antara IPA 
dengan mengembangkan rasa ingin tahu, sikap positif dan kesadaran tentang adanya, lingkungan, teknologi dan masyarakat. Untuk menyelidiki alam sekitar, memecahkan masalah melalui pengembangan ketrampilan proses, dan membuat keputusan. Untuk berperan serta dalam memelihara, menjaga dan melestarikan lingkungan alam perlu ditingkatkan kesadaran. Sebagai dasar untuk melanjutkan pendidikan ke SMP dengan memperoleh bekal pengetahuan, konsep dan keterampilan IPA.

Ruang lingkup dalam penelitian iniadalah bahan kajian mata pelajaran IPA di SD yang meliputi aspek-aspek : (1) Manusia, hewan, tumbuhan dan interaksinya dengan lingkungan serta kesehatan yang disebut dengan makhluk hidup dan proses kehidupan (2) Benda cair, padat dan gas yang merupakan benda/materi, sifat-sifat dan kegunaannya (3) Yang meliputi: gaya, bunyi, panas, magnet, listrik, cahaya dan pesawat sederhana, yaitu merupakan energi dan perubahannya (4) Yang meliputi: tanah, bumi, tata surya, dan benda-benda langit. Semua permasalahan tersebut diatas merupakan permasalahan nyata yang belum sesuai dengan saran dalam KTSP tentang pembelajaran IPA. Pada pembelajaran IPA Kualitas yang masih rendah tersebut juga ditemukan di SDN 211/IX Mendalo Darat.

Hal ini diperkuat dengan adanya beberapa kendala, diantaranya guru sudah berperan sebagai informan yang sangat menguasai materi ajar, namun masih kurang adanya variasi dalam penyampaiannya, dampaknya pun peserta didik menjadi kurang termotivasi. Selain itu, guru kurang menghadirkan suatu permasalahan yang relevan dengan kehidupan sehari-hari peserta didik. Guru kurang melibatkan peserta didik dalam penyelidikan, sehingga peserta didik kurang dapat melakukan penyelidikan guna menghasilkan pemecahan masalah.

Konsep-konsep yang dikuasai peserta didik hanya diberikan secara hafalan oleh guru, peserta didik kurang dibelajarkan melalui proses penemuan-penemuan yang berorientasi pada masalah dalam kehidupan sehari-hari. Kurang optimal dalam memfasilitasi peserta didik untuk melaksanakan suatu kegiatan percobaan. Kurang mengajarkan peserta didik bekerja secara berkelompok dan mengajarkan peserta didik mengenai merancang percobaan sampai merancang kesimpulan dari hasil percobaan dan menemukan pemecahan masalah secara sistematis. Permasalahan lain yaitu kurang adanya apresiasi terhadap pekerjaan atau hasil karya peserta didik. Sehingga dalam pembelajaran kurang mengembangkan hasil karya peserta didik atau berupa produk.

Masalah yang akan dikaji berdasarkan latar belakang masalah tersebut dengan melakukan penelitian tindakan kelas berjudul "Penerapan model Problem Based Instruction (PBI) dengan media kartu pintar untuk meningkatkan kualitas pembelajaran IPA pada peserta didik kelas IV SDN 211/IX Mendalo Darat".

Selain membutuhkan media sebagai alat peraga pembelajaran dalam pembelajaran IPA, sebaiknya juga menggunakan keterampilan proses IPA. Ada dua tingkatan dalam ketrampilan proses yaitu keterampilan proses tingkat dasar (basic science process skill) dan keterampilan proses terpadu (integrated science process skill). Keterampilan tingkat dasar terdiri dari: observasi, klasifikasi, komunikasi, pengukuran, prediksi, dan inferensi. Yang termasuk dalam ketrampilan proses menentukan variabel, menyusun tabel data, menyusun grafik, memberi hubungan variabel, memproses data, menganalisis penyelidikan, menyusun hipotesis, menentukan variabel secara operasional, merencanakan penyelidikan, dan melakukan eksperimen. (Trianto, 2010).

Pembelajaran IPA menggunakan model Problem Based Instruction dengan media kartu pintar berdasarkan uraian di atas, dapat disimpulkan bahwa pembelajaran IPA yang mempelajari alam dan lingkungan dengan pembelajaran yang membutuhkan penelitian atau eksperimen semakin terdukung apabila menerapkan model Problem Based Instruction, karena model pembelajaran ini bertujuan untuk melatih peserta didik berpikir tingkat tinggi dengan keterampilan memecahkan masalah. Sehingga, akan mengembangkan keterampilan bereksperimen dan menumbuhkan sikap ilmiah pada peserta didik. Selain itu, memberikan kesempatan kepada peserta didik untuk belajar menemukan sendiri sesuai dengan pengalamannya. Peserta didik dituntut untuk melakukan percobaan berdasarkan pada masalah yang nyata, hal ini sejalan dengan pebelajaran IPA yang kegiatan belajarnya akan lebih bermakna jika melakukan percobaan, sehingga peserta didik akan mendapatkan pengetahuan berdasarkan percobaan yang dilakukannya.

\section{LANDASAN TEORI}

Model pembelajaran yang menggunakan permasalahan autentik dengan tujuan untuk menyusun pengetahuan peserta didik merupakan model pembelajaran berbasis masalah, mengembangkan inkuiri dan keterampilan tingkat tinggi. Pengertian pembelajaran berbasis masalah juga disampaikan oleh Rusman, pembelajaran berbasis masalah merupakan inovasi dalam pembelajaran karena dalam pembelajaran berbasis masalah kemampuan berpikir peserta didik betul-betul dioptimalisasikan melalui proses kerja tim/kelompok yang sistematis, peserta didik akan dapat memberdayakan, mengasah, menguji, dan mengembangkan kemampuan berpikirnya secara berkesinambungan. Inovasi yang paling signifikan dalam pendidikan disebut dengan pembelajaran berbasis masalah merupakan inovasi yang paling signifikan dalam pendidikan. Untuk meningkatkan perkembangan keterampilan belajar sepanjang hayat dalam pola pikir yang terbuka, reflektif, kritis, dan belajar aktif dibantu dalam kurikulum pembelajaran berbasis masalah memfasilitasi keberhasilan memecahkan masalah, komunikasi, kerja kelompok dan keterampilan interpersonal dengan lebih baik dibanding pendekatan yang lain.

Berdasarkan uraian di atas, dapat disimpulkan bahwa pembelajaran berbasis masalah merupakan salah satu model pembelajaran yang mengasah kemampuan berpikir peserta didik dengan melakukan percobaan secara langsung 
sehingga dapat membantu anak agar dapat meningkatkan perkembangan keterampilan belajar dengan pola pikir yang terbuka, kritis, reflektif dan belajar aktif, karena peserta didik mengalami sendiri dengan menemukan sendiri.

Berdasarkan uraian diatas model pembelajaran Problem Based Instruction , penggunaan langkah-langkah model pembelajaran Problem Based Instruction dengan media kartu pintar dalam pembelajaran IPA mengacu pada langkah-langkah tersebut yaitu sebagai berikut :

a. Orientasi peserta didik pada masalah yaitu mengajukan permasalahan melalui pertanyaan serta menyampaikan tujuan pembelajaran dan memotivasi peserta didik untuk mengikuti pembelajaran.

b. Mengorganisasi peserta didik untuk belajar yaitu menjelaskan materi dengan menggunakan kartu pintar, membentuk kelompok kecil untuk mengidentifikasi masalah.

c. Membimbing penyelidikan individual atau kelompok yaitu membimbing serta memfasilitasi peserta didik dalam melaksanakan percobaan sesuai dengan pemecahan masalah yang telah direncanakan.

d. Mengembangkan dan menyajikan hasil karya yaitu membimbing peserta didik mengerjakan lembar kerja kelompok dan menyajikan hasil karya lain, seperti gambar percobaan.

e. Menganalisis dan mengevaluasi proses pemecahan masalah yaitu membimbing peserta didik mempresentasikan pemecahan masalah yang dilakukan dan menganalisis serta mengevaluasi proses pemecahan masalah yang dilakukan.

Penggunaan media kartu pintar seperti permainan yang harus dimainkan oleh 4 anak Hermina (2013). Setiap kartu berisi rangkuman materi. Kemudian disiapkan pula membuat alat peraga pendukung, misalnya bagian tubuh manusia. Media kartu pintar berbasis cetakan akan lebih berguna untuk pembelajaran jika memperhatikan format penggunaannya serta hendaknya dapat dirawat dengan baik agar tidak mudah rusak dapat disimpulkan berdasarkan uraian diatas, Peneliti menggunakan media kartu pintar karena dianggap akan lebih menarik bagi peserta didik dan efektif untuk digunakan.

Kondisi seperti yang telah diuraikan di atas, memerlukan suatu perbaikan kualitas pembelajaran, salah satu diantaranya yaitu dengan menerapkan model pembelajaran yang lebih baik dan sesuai dengan kebutuhan peserta didik dalam pembelajaran. Model pembelajaran yang diterapkan Untuk mengatasi permasalahan yang sedang terjadi model pembelajaran yang diterapkan. Mata pelajaran IPA yang mempelajari tentang alam akan lebih bermakna dan bervariasi jika menggunakan alat bantu atau alat peraga untuk menyampaikan materi ajarnya yang digunakan mata pelajaran IPA yang mempelajari tentang alam akan lebih bermakna dan bervariasi Selain memudahkan peserta didik untuk mengingat kembali, dengan adanya media pembelajaran juga akan membengkitkan imajinasi dan pembelajaran menjadi lebih bermakna bagi peserta didik. Oleh karena itu diharapkan guru yang berperan sebagi fasilitator dapat menerapkan model pembelajaran dengan menggunakan media pembelajaran yang bervariasi dan sesuai dengan kebutuhan peserta didik.

Penerapan model Problem Based Instruction dengan media kartu pintar diharapkan dapat memberikan beberapa manfaat dalam kegiatan pembelajaran agar tercapai pembelajaran yang optimal. Berdasarkan uraian di atas, peneliti mencari pemecahan masalah melalui penerapan model Problem Based Instruction dengan media kartu pintar untuk meningkatkan kualitas pembelajaran IPA di kelas IV SDN 211/IX Mendalo Darat.

\section{METODE PENELITIAN}

Subyek penelitian ini adalah guru (peneliti), peserta didik kelas IV SDN 211/IX Mendalo Darat sebanyak 37 peserta didik, terdiri dari 22 peserta didik perempuan dan 15 peserta didik laki-laki. Pada pengamatan aktivitas peserta didik terfokuskan pada 12 peserta didik, terdiri dari 5 laki-laki dan 7 perempuan.

Pelaksanaan PTK menurut Arikunto menyatakan bahwa secara garis besar terdapat empat tahapan yang lazim dilalui dalam melaksanakan penelitian tindakan terdiri dari beberapa langkah yaitu: perencanaan, pelaksanaan, pengamatan, dan refleksi.

1. Perencanaan (planning)

Tahap perencanaan ini meliputi perencanaan RPP sesuai dengan standar kompetensi, kompetensi dasar, indikator, dan materi belajar yang akan disampaikan. Dijelaskan tentang apa, mengapa, kapan, di mana, oleh siapa, dan bagaimana tindakan tersebut dilakukan dalam tahapan oleh peneliti

2. Pelaksanaan (acting)

Pada tahap pelaksanaan tindakan ini dilakukan di dalam kelas dengan menerapkan rencana pelaksanaan yang telah dibuat, yaitu model pembelajaran Problem Based Instruction dengan media kartu pintar. Dalam penelitian tindakan kelas tahap pelaksanaan merupakan suatu kegiatan inti, karena observasi dan pelaksanaan penilaian di dalam pelaksanaan akan dilakukan

3. Observasi (Observing)

Observasi dilaksanakan pada tahapan ini kegiatan secara kolaburatif dengan guru kelas untuk mengamati kegiatan pembelajaran pada peserta didik kelas IV SDN 211/IX Mendalo Darat. Pada kegiatan observasi ini, peneliti menekankan pada keterampilan guru dan aktivitas peserta didik dalam pembelajaran IPA melalui model Problem Based Instruction dengan media kartu pintar, sedangkan hasil belajar peserta didik dilakukan dengan penilaian evaluasi. 


\section{Refleksi (Reflecting)}

Pada tahapan ini Refleksi adalah kegiatan untuk mengemukakan kembali apa yang sudah dilakukan. Ketika guru pelaksana sudah selesai melakukan tindakan, kegiatan refleksi ini sangat tepat dilakukan kemudian berhadapan dengan peneliti untuk mendiskusikan implementasi rancangan tindakan. Terdiri atas 4 komponen kegiatan refleksi itu yaitu: analisis data hasil observasi, pemaknaan data hasil analisa, penjelasan hasil analisa, dan penyimpulan apakah masalah itu selesai/teratasi atau tidak. Arikunto (2010). Diperlukan perbaikan pada siklus berikutnya jika belum teratasi dan apabila sudah teratasi, maka peneliti harus tetap melakukan refleksi terhadap kekurangan-kekurangan yang terjadi sehingga dapat dilaksanakan perbaikan pada proses pembelajaran selanjutnya demi meningkatkan dan mempertahankan mutu pembelajaran. Setelah mengkaji proses pembelajaran yaitu mengenai keterampilan guru, aktivitas peserta didik, dan hasil belajar dalam pembelajaran IPA melalui model problem based instruction dengan media kartu pintar, Pada siklus pertama untuk dilakukan perbaikan pada siklus selanjutnya maka peneliti akan membuat daftar permasalahan yang masih belum teratasi.

\section{HASIL DAN PEMBAHASAN}

Hasil penelitian tindakan kelas dengan menerapkan model Problem Based Instruction (PBI) yang dilaksanakan di SDN 211/IX Mendalo darat ini meliputi hasil kegiatan pengamatan terhadap keterampilan guru, aktivitas peserta didik, dan hasil belajar peserta didik kelas IV. Data kualitatif yaitu keterampilan guru dan aktivitas peserta didik diperoleh dari hasil pengamatan saat pembelajaran berlangsung. Sedangkan data kuantitatif diperoleh dari soal evaluasi yang diberikan di setiap akhir siklus, untuk mengukur tingkat pemahaman peserta didik terhadap materi energi panas dan bunyi. Dilaksanakan dalam 3 siklus yang dilaksanakan dalam penelitian tindakan kelas , dengan masing-masing siklus 2 kali pertemuan.

Berikut akan dipaparkan hasil penelitian yang terdiri atas keterampilan guru, aktivitas peserta didik, dan hasil belajar peserta didik dalam pembelajaran IPA melalui model Problem Based Instruction (PBI) dengan media kartu pintar pada peserta didik kelas IV SDN 211/IX Mendalo Darat. Dalam pembelajaran IPA Keterampilan guru melalui model Problem Based Instruction (PBI) dengan media kartu pintar berdasarkan pengamatan pada siklus I pertemuan 1 dan 2 diperoleh data sebagai berikut :

Tabel 1

Data Hasil Observasi Keterampilan Guru Siklus I

\begin{tabular}{|c|c|c|c|c|c|c|c|}
\hline \multirow[t]{2}{*}{ No } & \multirow[t]{2}{*}{ Indikator Pengamatan } & \multicolumn{2}{|c|}{ Pertemuan Ke } & \multirow[t]{2}{*}{ Rata-Rata } & \multirow[t]{2}{*}{ Persentase } & \multirow[t]{2}{*}{ Kriteria } & \multirow{2}{*}{$\begin{array}{c}\text { Tingkat } \\
\text { Keberhasilan }\end{array}$} \\
\hline & & 1 & 2 & & & & \\
\hline 1 & $\begin{array}{l}\text { Melakukan Pra kegiatan } \\
\text { pembelajan }\end{array}$ & 3 & 4 & 3,5 & $87,5 \%$ & B & Berhasil \\
\hline \multicolumn{8}{|c|}{ Orientasi Siswa Pada Masalah } \\
\hline 2 & $\begin{array}{l}\text { Menginformasi tujuan } \\
\text { pembelajaran }\end{array}$ & 2 & 2 & 2 & $50 \%$ & $\mathrm{C}$ & Tidak Berhasil \\
\hline 3 & $\begin{array}{l}\text { Memotivasi siswa terlibat } \\
\text { dalam pemecahan masalah }\end{array}$ & 2 & 2 & 2 & $50 \%$ & $\mathrm{C}$ & Tidak Berhasil \\
\hline \multicolumn{8}{|c|}{ Mengorganisasi siswa untuk belajar } \\
\hline & $\begin{array}{ll}\text { Membantu } & \text { siswa } \\
\text { mengorganisasikan } & \text { tugas } \\
\text { pemecahan masalah } & \\
\end{array}$ & 2 & 3 & 2,5 & $62,5 \%$ & $\mathrm{C}$ & Tidak Berhasil \\
\hline \multicolumn{8}{|c|}{ Memberi pengarahan individual atau kelompok } \\
\hline 5 & $\begin{array}{l}\text { Membimbing siswa } \\
\text { melakukan pendidikan }\end{array}$ & 2 & 2 & 2 & $50 \%$ & $\mathrm{C}$ & Tidak Berhasil \\
\hline \multicolumn{8}{|c|}{ Mengembangkan dan menyajikan hasil karya } \\
\hline 6 & $\begin{array}{ll}\text { Membimbing } & \text { siswa } \\
\text { menyiapkan karya } & \text { untuk } \\
\text { disajikan } & \end{array}$ & 2 & 3 & 2,5 & $62,5 \%$ & $\mathrm{C}$ & Tidak Berhasil \\
\hline 7 & $\begin{array}{l}\text { Membantu siswa untuk } \\
\text { melakukan evaluasi proses } \\
\text { pemecahan masalah }\end{array}$ & 2 & 3 & 2,5 & $62,5 \%$ & $\mathrm{C}$ & Tidak Berhasil \\
\hline 8 & $\begin{array}{l}\text { Memberian reward kepada } \\
\text { siswa/kelompok }\end{array}$ & 3 & 2 & 2,5 & $62,5 \%$ & $\mathrm{C}$ & Tidak Berhasil \\
\hline \multirow[t]{4}{*}{9} & Menutup pembelajaran & 2 & 2 & 2 & $50 \%$ & $\mathrm{C}$ & Tidak Berhasil \\
\hline & Total Skor & 20 & 23 & 21,5 & - & - & - \\
\hline & Persentase & $57 \%$ & $63,9 \%$ & $60 \%$ & - & - & - \\
\hline & Rata-rata & 2,2 & 2,6 & 2,3 & $60 \%$ & $\mathbf{C}$ & $\begin{array}{c}\text { Tidak } \\
\text { Berhasil }\end{array}$ \\
\hline
\end{tabular}


Hasil Observasi keterampilan guru berdasarkan paparan data pada pembelajaran IPA melalui model Problem Based Instruction dengan media kartu pintar pada siklus I pertemuan 1 memperoleh skor rata-rata 2,2 dan pertemuan 2 dengan skor rata-rata 2,6. Sehingga diperoleh skor rata-rata siklus I adalah 2,3 dengan persentase $60 \%$ dengan kriteria cukup (C). Keterampilan guru pada siklus I dinyatakan belum berhasil berdasarkan kualifikasi skor yang diperoleh simpulan

Hasil pengamatan aktivitas peserta didik siklus I diperoleh dengan mengamati 12 siswa kelas IV SDN 211/IX Mendalo Darat yang mengikuti pembelajaran IPA materi energi panas dan energi bunyi terdiri dari peserta didik 5orang laki-laki dan peserta didik 7 orang perempuan.

Berdasarkan data dan uraian hasil observasi aktivitas peserta didik pada pembelajaran IPA melalui model Problem Based Instruction dengan media kartu pintar pertemuan 1 dan 2, diperoleh hasil atas pelaksanaan tindakan yang dilakukan pada siklus I. Hasil skor rata-rata dari sembilan indikator yang diamati pada pertemuan 1 adalah 2,3 $(57,5 \%)$ dan pertemuan 2 meningkat dengan skor rata-rata 2,6 (65\%). Berdasarkan skor yang diperoleh pada pertemuan 1 dan 2 pada siklus I maka diperoleh skor rata-rata pengamatan aktivitas peserta didik siklus I sebesar 2,4 dengan persentase $60 \%$ dengan kriteria cukup (C). Dengan demikian, simpulan sementara yang dapat diperoleh dari data tersebut adalah aktivitas belajar peserta didik pada mata pelajaran IPA melalui model Problem Based Instruction diperlukan tindak lanjut sebagai perbaikan pada siklus selanjutnya media kartu pintar siklus I belum berhasil.

Hasil belajar peserta didik pada siklus I diperoleh dari hasil evaluasi dengan menggunakan tes di akhir yaitu tes tertulis pembelajaran IPA dengan materi energi panas dan energi bunyi menerapkan model Problem Based Instruction (PBI) dengan media kartu pintar. Banyaknya peserta didik yang mengikuti kegiatan tes ini adalah 37 peserta didik. Pada kegiatan pembelajaran IPA hasil tes melalui model Problem Based Instruction (PBI) dengan media kartu pintar dapat dilihat sebagai berikut:

Tabel 2

Data Hasil Belajar Peserta Didik Siklus I

\begin{tabular}{|c|c|c|c|c|}
\hline \multirow{2}{*}{ No. } & \multirow{2}{*}{ Kriteria } & \multicolumn{2}{|c|}{ Pertemuan ke- } & \multirow{2}{*}{ Rata-rata } \\
\hline & & 1 & 2 & \\
\hline 1. & Rata-rata kelas & 65,6 & 65,8 & 66 \\
\hline 2. & Nilai tertinggi & 97 & 87 & 92 \\
\hline 3. & Nilai terendah & 43 & 50 & 47 \\
\hline 4. & Siswa tuntas & 19 & 22 & 21 \\
\hline 5. & Siswa yang belum tuntas & 18 & 15 & 16 \\
\hline & Mean & 65,6 & 65,8 & - \\
\hline & Median & 67 & 67 & - \\
\hline & Modus & 72 & 67 & - \\
\hline
\end{tabular}

Berdasarkan tabel di atas di atas bahwa hasil belajar IPA melalui model Problem Based Instruction (PBI) dengan media kartu pintar pada peserta didik kelas IV memperoleh nilai rata-rata 66. Nilai tertinggi pertemuan 1 adalah 97 dan pertemuan 2 adalah 87 sehingaa diperoleh nilai tertinggi rata-rata yaitu 92. Nilai terendah siklus I dengan rata-rata 47 dan peserta didik yang tuntas utuk pertemuan 1 yaitu 19 peserta didik dan pertemuan 2 yaitu 22 peserta didik. Sedangkan peserta didik yang belum tuntas rata-rata yaitu sebanyak 17 peserta didik.

Berdasarkan data yang diperoleh di atas, berikut rekapitulasi data keterampilan guru, aktivitas peserta didik, dan hasil belajar pada siklus I.

\section{Tabel 3}

\section{Rekapitulasi Data Hasil Pelaksanaan Tindakan Siklus I}

\begin{tabular}{ccc}
\hline Variabel Penelitian & Persentase & Tingkat Keberhasilan \\
\hline Keterampilan Guru & $60 \%$ & Tidak Berhasil \\
Aktivitas Siswa & $60 \%$ & Tidak Berhasil \\
Hasil Belajar & $55,41 \%$ & Tidak Berhasil \\
\hline
\end{tabular}

Berdasarkan diagram di atas menunjukkan bahwa keterampilan guru mendapatkan persentase skor 60\% dengan kriteria cukup (C) dengan tingkat keberhasilan belum berhasil. Aktivitas peserta didik mendapat persentase skor $60 \%$ dengan kriteria cukup (C) dan belum berhasil. Aktivitas peserta didik yang belum mencapai keberhasilan dikarenakan keterampilan guru dalam pembelajaran masih belum berhasil, sehingga 
menjadikan hasil belajar peserta didik rendah yaitu dengan persentase ketuntasan 55,41\% dan tingkat keberhasilan belum berhasil. Sehingga perlu dilakukan refleksi dan revisi untuk pelaksanaan siklus II.

Data hasil karya peserta didik pada siklus II menunjukkan perolehan skor pada pertemuan 1 dan 2 . Skor ratarata pada pertemuan 1 adalah 2,5 (63\%) dan pertemuan 2 meningkat dengan skor 2,7 (68\%). Sehingga, skor rata-rata siklus II adalah 2,6 dengan persentase 65\% dengan kriteria cukup (C). Dengan demikian, simpulan sementara untuk aktivitas peserta didik pada pembelajaran IPA melalui model Problem Based Instruction dengan media kartu pintar peserta didik kelas IV SDN 211/IX Mendalo Darat belum berhasil, karena belum mencapai tingkat persentase keberhasilan yang ditentukan.

Pengamatan keterampilan guru, aktivitas peserta didik, dan hasil belajar peserta didik telah dijelaskan di atas. Berikut rekapitulasi uraian hasil pelaksanaan tindakan siklus II terhadap variabel keterampilan guru, aktivitas peserta didik, dan hasil belajar peserta didik.

\section{Tabel 4}

Rekapitulasi Data Hasil Pelaksanaan Tindakan Siklus II

\begin{tabular}{ccc}
\hline Variabel Penelitian & Persentase & Tingkat Keberhasilan \\
\hline Keterampilan Guru & $75 \%$ & Berhasil \\
Aktivitas Siswa & $68 \%$ & Berhasil \\
Hasil Belajar & $67,6 \%$ & Tidak Berhasil \\
\hline
\end{tabular}

Berdasarkan tabel di atas, menunjukkan data pelaksanaan tindakan pada siklus II yang dibandingkan dengan siklus I. Peningkatan terlihat mulai dari keterampilan guru pada siklus II adalah $68 \%$ dengan kriteria baik (B). Aktivitas peserta didik dengan persentase 68\%, dan hasil belajar dengan persentase 67,6\% dengan kriteria cukup (C). Sehingga dapat disimpulkan bahwa pelaksanaan tindakan pada siklus II dinyatakan belum berhasil.

Pengamatan keterampilan guru, aktivitas peserta didik, dan hasil belajar peserta didik telah dijelaskan di atas. Berikut rekapitulasi uraian hasil pelaksanaan tindakan siklus III terhadap variabel keterampilan guru, aktivitas peserta didik, dan hasil belajar peserta didik.

\section{Tabel 5}

Rekapitulasi Data Hasil Pelaksanaan Tindakan Siklus II

\begin{tabular}{ccc}
\hline Variabel Penelitian & Persentase & Tingkat Keberhasilan \\
\hline Keterampilan Guru & $85 \%$ & Berhasil \\
Aktivitas Siswa & $88 \%$ & Berhasil \\
Hasil Belajar & $81 \%$ & Berhasil \\
\hline
\end{tabular}

Berdasarkan diagram 4.18 menunjukkan terjadi peningkatan dari keterampilan guru pada siklus II dengan persentase $75 \%$ menjadi $85 \%$ pada siklus. Aktivitas peserta didik meningkat dari persentase $68 \%$ menjadi $88 \%$ pada siklus III, dan hasil belajar peserta didik dari persentase 67,6\% meningkat pada siklus II menjadi $81 \%$. Sehingga dapat disimpulkan bahwa data pengamatan pada siklus III dengan variabel keterampilan guru, aktivitas peserta didik, dan hasil belajar peserta didik meningkat dan dapat dikategorikan berhasil.

Penelitian pembelajaran IPA bagi sekolah melalui model Problem Based Instruction dengan media kartu pintar dapat dijadikan sebagai upaya yang dapat menumbuhkan kerja sama antar guru yang berdampak positif pada kualitas dapat memberikan kontribusi yang lebih baik dalam perbaikan pembelajaran pada kualitas pembelajaran di sekolah untuk meningkatkan kualitas pembelajaran IPA khususnya di Sekolah Dasar. Melalui model Problem Based Instruction dengan media kartu pintar, maka dapat menjadi referensi untuk meningkatkan mutu pendidikan di sekolah dengan adanya peningkatan kualitas pembelajaran IPA

\section{SIMPULAN}

Berdasarkan hasil penelitian dan pembahasan mengenai peningkatan kualitas pembelajaran IPA melalui model Problem Based Instruction dengan media kartu pintar pada peserta didik kelas IV SDN 211/IX Mendalo Darat diperoleh simpulan sebagai berikut :

1. Penerapan model Problem Based Instruction (PBI) dengan media kartu pintar dapat meningkatkan keterampilan dasar mengajar guru pada pembelajaran IPA peserta didik kelas IV SDN 211/IX Mendalo Darat. Hal ini dibuktikan dengan meningkatnya perolehan skor keberhasilan keterampilan mengajar guru dari siklus I sebesar 21,5 dengan persentase 60\% dengan kriteria cukup (C) meningkat pada siklus II jumlah skor 23,65 dengan 
persentase skor 75\% dengan kriteria baik (B) dan siklus III jumlah skor 30,5 dengan persentase skor 85\% dengan kriteria (B). berdasarkan data tersebut dapat terlihat bahwa terjadi peningkatan pada keterampilan guru setiap siklus pelaksanaannya. Dari data tersebut dapat disimpulkan keterampilan guru telah mencapai indikator keberhasilan dengan kriteria sekurang-kurangnya aktif dengan skor $25 \mathrm{~s} / \mathrm{d} 32$.

2. Aktivitas belajar peserta didik kelas IV pada pembelajaran IPA meningkat dengan menerapkan model Problem Based Instruction dengan media kartu pintar. Peningkatan ini ditunjukkan dengan perolehan skor aktivitas belajar peserta didik siklus I sebesar 21,85 persentase 60\% dengan kriteria cukup (C), siklus II memperoleh jumlah skor sebesar 24,35 dengan persentase 68\% kriteria cukup (C), dan siklus III memperoleh jumlah skor sebesar 31,2 dengan persentase $88 \%$ kriteria baik (B). Berdasarkan data tersebut dapat terlihat bahwa aktivitas siswa mengalami peningkatan pada tiap siklus pelaksanaan. Berdasarkan data tersebut dapat disimpulkan aktivitas peserta didik telah mencapai indikator keberhasilan dengan kriteria sekurang-kurangnya aktif dengan skor $25 \mathrm{~s} / \mathrm{d} 32$.

3. Melalui model Problem Based Instruction dengan media kartu pintar pada pembelajaran IPA pokok bahasan energi panas dan energi bunyi kelas IV SDN 211/IX Mendalo Darat dapat meningkatkan hasil belajar peserta didik. Hal ini ditunjukkan dengan peningkatan hasil belajar peserta didik kelas IV pada setiap siklusnya. Berdasarkan hasil evaluasi pada setiap siklusnya diperoleh data pada siklus I dengan nilai terendah pertemuan 1 adalah 43 dan pertemuan 2 adalah 53, nilai tertinggi pertemuan 1 adalah 97 dan pertemuan 2 adalah 87, rata-rata kelas pertemuan 1 adalah 65,6 dan pertemuan 2 adalah 65,8, sehingga rata-rata kelas untuk siklus I adalah 65,7 dan ketuntasan klasikal 55,41\%. Pada pelaksaanaan tindakan siklus II diperoleh data hasil belajar dengan nilai terendah 57, nilai tertinggi 100 dengan rata-rata kelas 74,3 dan mencapai ketuntasan klasikal 67,57\%. Pada pelaksanaan tindakan siklus III hasil belajar peserta didik yang diperoleh dengan nilai terendah 57, nilai tertinggi 100, rata-rata 76,4 dan persentase ketuntasan klasikal $81 \%$. Dapat disimpulkan bahwa hasil belajar IPA peserta didik kelas IV sudah memenuhi indikator keberhasilan yaitu ketuntasan klasikal seluruh peserta didik mencapai $80 \%$.

Berdasarkan hasil penelitian yang telah dilaksanakan, peningkatan kualitas pembelajaran IPA melalui model Problem Based Instruction (PBI) dengan media kartu pintar pada peserta didik kelas IV SDN 211/IX Mendalo Darat, saran yang dapat diberikan adalah sebagai berikut :

Agar pelaksanaan pembelajaran yang menggunakan model Problem Based Instruction (PBI) lebih produktif, hendaknya guru melakukan persiapan dan perencanaan yang matang disesuaikan dengan kondisi sekolah untuk menyajikan kegiatan pembelajaran. Perencanaan tersebut meliputi : 1) pemilihan materi atau konsep yang akan disampaikan, 2) lembar kerja untuk peserta didik yang akan digunakan, 3) media dan alat peraga yang sesuai dengan materi dan menarik untuk peserta didik, 4) kegiatan penyelidikan yang akan dilaksanakan, 5) strategi atau metode yang akan digunakan, 6) instrumen evaluasi yang tepat untuk mengukur tingkat keberhasilan peserta didik.

Perlu diadakan pelatihan yang efektif bagi guru untuk melaksanakan pembelajaran dengan model Problem Based Instruction (PBI) dengan media kartu pintar. Demikian halnya bagi peserta didik, perlu diadakan latihan yang efektif bagi peserta didik untuk melaksanakan pembelajaran dengan model Problem Based Instruction (PBI) dengan media kartu pintar, agar dapat diciptakan kondisi pembelajaran sesuai dengan yang diharapkan.

Dalam menerpakan model Problem Based Instruction (PBI) dengan media kartu pintar, sebaiknya peserta didik dikondisikan dalam kelompok kecil pembelajaran agar tercipta komunikasi yang positif untuk pelaksanaan kegiatan penyelidikan. Di samping itu, sebaiknya pembelajaran IPA bukan hanya menekankan pada hasil pembelajaran saja, namun harus diseimbangkan dengan proses pembelajarannya yang disesuaikan dengan keterampilan proses pada pembelajaran IPA. Selain itu, dapat mengembangkan keterampilan sosial peserta didik dalam pembelajarannya, seperti; mendengarkan dengan aktif pada saat guru menjelaskan, mendorong teman dalam kelompoknya untuk berpartisipasi dalam penyelidikan, dan berani bertanya mengenai materi yang belum diketahui.

\section{DAFTAR PUSTAKA}

Aqib, Zainal, dkk. 2011. Penelitian Tindakan Kelas Untuk Guru SD,SLB, TK. Bandung: CV. Yrama Widya

Arsyad, Azhar. 2011. Media Pembelajaran. Jakarta: PT Raja Grafindo Persada

Badan Standar Satuan Pendidikan (BSNP). 2007. Standar Proses. Jakarta : Badan Standar Satuan Pendidikan.

Cakudik. 2012. Revisi Taksonomi Bloom. Tersedia pada: [online]

http://mgmpmatsatapmalang.wordpress.com/2012/07/07/taksonomi-bloom-versi-baru/diunduhpada 31 januari 2013 pukul 22.03

Gunanto, Muhammad Okto. 2012. Peningkatan Kualitas Pembelajaran IPA Melalui Model Pembelajaran Problem Based Instrction pada Kelas IVB SD Negeri Tambakaji 01 Semarang. Skripsi: UNNES

Hakim, Luqman. 2012. Jurnal Pendidikan dengan Model Problem Based Instruction. Tersedia pada : [online] http://journal.uns.ac.id/index.php/diunduhpada 28 Februari 2013 pukul 09.01

Hamdani. 2011. Strategi Belajar Mengajar. Bandung: CV. Pustaka Setia

Indriana, Dina. 2011. Ragam Alat Bantu Media Pengajaran. Jogjakarta: DIVA Press 
Iwan.2012. Media Kartu Pintar. Tersedia pada: [online] http://iwansmtri.blogspot.com/2012/09/belajar-matematikadengan-kartu-kemudi.html. diunduh pada 1 Februari 2013 pukul 10.11

Labolatorium Pengembangan Pendidikan dan Pembelajaran Islam (LP3I). 2010. Keterampilan Dasar Mengajar. Jogjakarta: Ar-Ruzz Media

Redaksi. 2012. Kartu Pintar Pada Pembelajaran IPA. Tersedia pada: [online] KORANPENDIDIKAN.com diunduh pada 6 Juli 2013 pukul 07.07

Rusman. 2012. Model-Model Pembelajaran Mengembangkan Profesionalisme

Guru. Jakarta: PT Grafindo Persada

Suharti, Eny. 2012. Kartu Pintar. Tersedia pada: [online] http://www.duniavirtual.com/anincoll/35467-kartupintar.htm diunduh 19 Januari pukul 07.33

Sutama. 2011. Metode Penelitian Pendidikan Kuantatif, Kualitatif, PTK, R\&D. Surakarta: Fairuz Media

Trianto. 2010. Model Pembelajaran Terpadu. Jakarta: Bumi Aksara Undang-Undang Permendiknas No 22 Tahun 2006 tentang Standar Isi.

Wahyudin. 2008. Pengantar Pendidikan. Jakarta: Universitas Terbuka.

Warpala, Sukra I Wayan. 2012. Teori Vygotsky.Tersedia pada : [online]

Widiyoko, Eko Putro. 2012. Teknik Penyusunan Instrumen Penelitian. Yogyakarta: Pustaka Pelajar

Widihastrini, Florentina. 2011. Materi Mata Kuliah Penelitian Pendidikan SD 2.

Semarang: PGSD UNNES 